\title{
Keterkaitan Megabentos yang Berasosiasi dengan Padang Lamun terhadap Karakteristik Lingkungan di Perairan Jepara
}

\author{
Ita Riniatsih*, Ambariyanto, Ervia Yudiati \\ Departemen IImu Kelautan, Fakultas Perikanan dan IImu Kelautan, Universitas Diponegoro \\ Jl. Prof Soedarto SH, Tembalang, Semarang Jawa Tengah 50275 Indonesia \\ Email: iriniatsih@yahoo.com
}

\section{Abstract \\ Relationship of Megabenthos Associated with Seagrass beds to Environmental Characteristics in Jepara Waters}

Seagrass bed are one of the ecosistems in shallow waters that can support the biodiversity of marine organisms. Megabenthos as benthic organisms that usually live in association in seagrass beds, have an important role in the food web in their habitat. This study aims to analyse the diversity of megabenthos associated with their habitat characteristics in seagrass waters in Bandengan, Teluk Awur and Panjang Island Jepara. This research was conducted using a descriptive field method, and megabenthos data collecting was carried out using the line transect method. Thr result showed that 158 individuals from 8 species of megabenthos were found (from 2 phyla: Echinodermata and Molluska) from three observation locations. Condition factors that influence the abundance and diversity of megabenthos are the substrat type and seagrass cover.

Keywords: megabenthos, association, seagrass bed, Jepara

\begin{abstract}
Abstrak
Padang lamun sebagai salah satu ekosistem di perairan laut dangkal dapat menopang keanekaragaman hayati organisme laut. Megabentos yang termasuk dalam organisme bentik merupakan organisme yang biasa hidup berasosiasi di padang lamun, mempunyai peranan penting dalam jaring-jaring makanan di habitatnya. Penelitian ini bertujuan untuk menganalisa keanekaragaman megabentos dikaitkan dengan karakteristik habitatnya di perairan padang lamun di Bandengan, Teluk Awur dan Pulau Panjang Jepara. Penelitian ini dilakukan dengan metoda deskriptif lapangan, dan pengambilan data megabentos dilakukan dengan metoda line transek. Hasil pengamatan menunjukkan ditemukan 158 individu dari 8 spesies megabentos (dari 2 filum: Echinodermata dan Molluska) dari ketiga lokasi pengamatan. Faktor kondisi yang berpengaruh terhadap kelimpahan dan keanekaragaman megabentos adalah jenis substrat dasar dan tutupan lamun.
\end{abstract}

Kata Kunci: megabentos, asosiasi, padang lamun, Jepara

\section{PENDAHULUAN}

Padang lamun sebagai salah satu ekosistem laut dangkal merupakan kawasan yang sangat produktif. Ekosistem ini mampu berfungsi menopang kehidupan dan menjaga tingginya keanekaragaman hayati di dalamnya (Park \& Kwak, 2018). Secara structural, ekosistem padang lamun mempunyai fungsi sebagai spawning ground, nursery ground, feeding ground untuk banyak spesies dari berbagai jenis organisme laut untuk menyediakan makanan, dalam rantai makanan, menjaga keanekaragaman dan ecosystem service dalam mendukung produktivitas perairan (Hantanirina \& Benbow, 
2013). Produktivitas primer dan sekunder padang lamun relatif tinggi, termasuk epifit dan alga bentik, yang dapat menghasilkan materi organik yang melimpah sehingga mampu mendukung kelimpahan dan keanekaragaman ikan dan organisme invertebrata bentik yang berasosiasi di dalamnya (Rahmawati et al., 2012).

Faktor penting yang dapat mengendalikan struktur komunitas fauna yang hidup di dalam ekosistem padang lamun adalah pola distribusi vegetasinya. Ekosistem padang lamun di perairan Jepara mempunyai keanekaragaman yang relatif beragam (Riniatsih et al., 2017). Hasil pengamatan menunjukkan terdapat 5 spesies lamun, yaitu Enhalus acoroides, Cymodocea serrulate, Cymodocea rotundata, Thalassia hemprichii, Halodule uninervis, Syringodium isoetifolium dan Halophila ovalis. Lamun tersebut tersebar di beberapa habitat di Pantai Prawean Bandengan, Teluk Awur dan Pulau Panjang. Kondisi padang lamun saat ini banyak mengalami penurunan yang diduga merupakan dampak masukan dari daratan, aktivitas masyarakat di wilayah pesisir, dan karena efek dari pemanasan global. Melimpahnya nutrien terlarut di padang lamun, sedimentasi, sampah plastik, lalu lintas kapal nelayan dan kapal wisata, serta aktivitas penangkapan ikan di padang lamun dapat memicu kerusakan padang lamun (Riniatsih, 2019). Selain itu efek pemanasan global yang mengakibatkan berubahnya pola pasang surut, naiknya suhu permukaan air laut, kondisi lamun sering terpapar sinar matahari, merupakan ancaman tersendiri yang dapat menurunkan kondisi padang lamun. Penurunan kondisi padang lamun tersebut dikhawatirkan dapat memberikan dampak menurunnya keanekaragaman biota laut yang hidup berasosiasi di padang lamun.

Megabentos, menurut Arbi \& Sihaloho (2017) adalah biota bentik dengan ukuran $>1 \mathrm{~cm}$. Biota bentik tersebut merupakan salah satu biota yang biasa ditemukan hidup di dasar perairan di ekosistem terumbu karang atau padang lamun. Biota bentik tersebut memiliki peranan yang sangat penting dalam jaring makanan, pemanfaatan bahan organik serta sebagai agen pendegradasi bahan organik di dasar perairan (Barus et al., 2019). Kelompok biota bentik ini sensitif terhadap faktor-faktor perubahan lingkungan, dengan berjalannya waktu, terjadinya perubahan iklim dapat mempengaruhi kondisi padang lamun dan kelimpahan biota bentik yang berasosiasi di dalamnya (Herawati et al., 2017; Arfiati et al., 2019). Banyak faktor yang mempengaruhi kelimpahan dan keanekaragaman megabentos di padang lamun, diantaranya adalah kondisi penutupan lamun dan jenis substrat dasar. Belum banyaknya penelitian yang melihat keanekaragaman megabentos di padang lamun terkait dengan karakteristik habitatnya di perairan Jepara. Untuk itu perlu dilakukan penelitian untuk melihat keanekaragaman megabentos di padang lamun di perairan Teluk Awur, Bandengan, dan Pulau Panjang Jepara terkait dengan karakteristik habitatnya. Tujuan dari penelitian ini adalah untuk mengetahui keanekaragaman dan kelimpahan megabentos di padang lamun terkait dengan karakteristik habitatnya, sehingga hasil yang diperoleh dapat dijadikan data dasar bagi pengelolaan wilayah pesisir, khususnya ekosistem padang lamun di perairan Jepara.

\section{MATERI DAN METODE}

Penelitian ini dilakukan pada bulan Maret dan September 2018. di padang lamun perairan Teluk Awur, Bandengan dan Pulau Panjang Jepara. Lokasi penelitian disajikan pada Gambar 1. Metode yang dipergunakan dalam pendataan megabentos mengacu pada Benthos Belt Transect (BBT) yang merupakan modifikasi dari metoda Belt Transect (Suharsono \& Sumadhiharga, 2014). Pengambilan data prosentase penutupan lamun dilakukan dengan metoda line transek kuadrat dan analisis data persentase penutupan lamun dihitung dengan mengacu pada Rahmawati et al. (2014). Fraksi substrat di tiap lokasi penelitian juga dianalisa berdasarkan Purnawan (2015) dan Udden (2015). Untuk melihat hubungan kelimpahan megabentos dengan lamun dan fraksi substrat dilakukan analisis regresi linier dengan SPSS Var 17. Indeks ekologi, yaitu untuk indeks keanekaragaman, indeks keseragaman dan indeks dominansi dianalisis berdasarkan Indrawan et al. (2016). Sedangkan untuk 
melihat keterkaitan antara kelimpahan megabentos dan karakteristik habitatnya yang meliputi parameter perairan (salinitas, suhu, oksigen terlarut, type substrat dasar, tutupan lamun, kecerahan, dan kedalaman perairan) dilakukan analisis dengan mempergunakan Principal Component Analysis (PCA) dan Correspondence Analysis (CA).

\section{HASIL DAN PEMBAHASAN}

Hasil pengamatan di tiga ekosistem padang lamun di perairan Jepara ditemukan lima spesies lamun, yaitu jenis Enhalus acoroides, Cymodocea serrulata, Cymodocea rotundata, Thalassia hemprichii, Halodule uninervis, Halophila ovalis dan Siringodium isoetifolium. Persentase penutupan lamun di ketiga lokasi pengamatan tidak banyak berubah di Bulan Maret dan September 2018, tercatat bahwa penutupan lamun yang terendah tercatat di perairan Teluk Awur (Gambar 2). Secara umum penutupan lamun $C$. serrulata mempunyai nilai yang terbesar di semua lokasi dan waktu pengamatan.
Jenis lamun yang ditemukan selama penelitian, tercatat 5 spesies lamun yang tersebar di ketiga lokasi penelitian, yaitu lamun jenis E. acoroides, C. serrulata, C. rotundata, $T$. hemprichii, $H$. ovali dan $S$. isoetifolium. Khususnya perairan Bandengan ditemukan lamun jenis Halodule uninerfis, namun tidak masuk dalam transek pengamatan. Keberadaan lamun di perairan Jepara sangat beragam, seperti penelitian yang telah dilakukan oleh Hartati et al. (2012) tercatat telah menemukan 6 species lamun di perairn pulau Kumbang, Karimunjawa. Penutupan lamun tertinggi di Bandengan (Stasiun Bl dan $B 2$ ), yang didominasi dengan lamun jenis $C$. serrulata. Diduga karena kondisi substrat dasar berupa pasir berlumpur merupakan substrat yang cocok untuk hidup lamun $C$. serrulata, disusul di lokasi Pulau Panjang (Stasiun PPI dan PP2) dengan penutupan lamun jenis $T$. hemprichii yang relatif tinggi (Gambar 1). Kondisi lamun yang relatif tinggi penutupannya di perairan Bandengan, diduga karena berdekatan dengan muara Sungai Sikembu yang memberikan sumbangan nutrien terlarut yang menunjang pertumbuhan lamun menjadi lebih tinggi
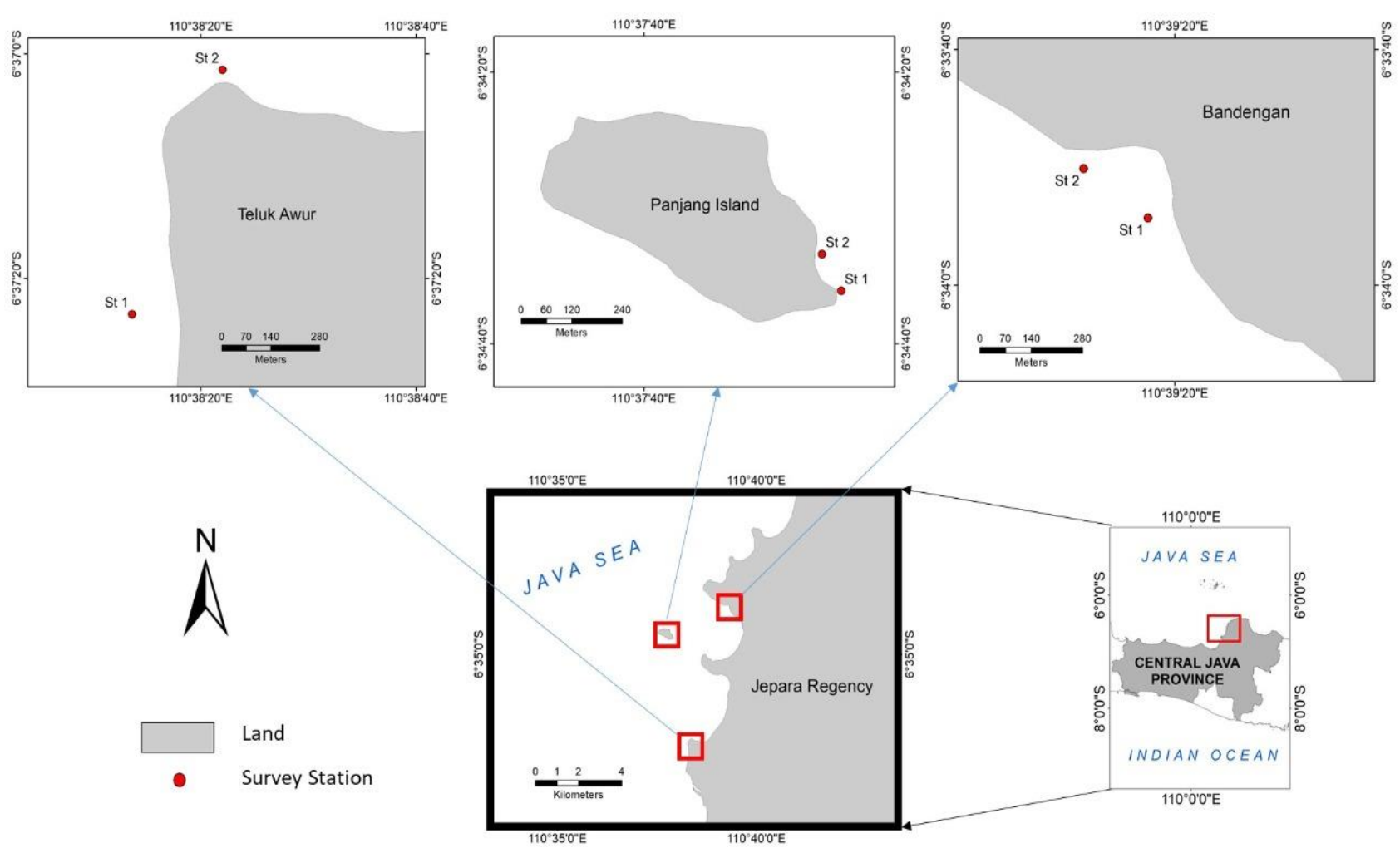

Gambar 1. Lokasi penelitian di perairan Bandengan, Teluk Awur dan Pulau Panjang Jepara 
dibanding lokasi lainnya. Menurut Riniatsih (2016) kandungan nutrien di perairan dapat mempengaruhi kondisi lamun di suatu habitat.

Hasil pengamatan megabentos, ditemukan delapan species megabentos di ketiga lokasi penelitian, yaitu Diadema setosum, Linnkia laevigata, Protoreaster nodosus, Holothuria atra, Pinctada sp., Anadara granosa, A. inequlvalvalis dan Drupela sp. Kelimpahan megabentos berkisar $0,03-0,15 \mathrm{ind} / \mathrm{m}^{2}$. Grafik tentang kelimpahan megabentos yang ditemukan di lokasi penelitian dapat dilihat pada Gambar 3.

Hasil pengamatan untuk megabentos di lokasi penelitian, ditemukan megabentos sebanyak 158 individu yang termasuk dalam delapan spesies dari filum Echinodermata dan Moluska. Kelimpahan megabentos terbanyak ditemukan di padang lamun Pulau Panjang (Stasiun PPI periode September), sebanyak $0,38 \mathrm{ind} / \mathrm{m}^{2}$, dan terendah di padang lamun Teluk Awur (Stasiun TA2 periode September) dan Pulau Panjang (Stasiun PP2 periode September) sebanyak 0,13 ind $/ \mathrm{m}^{2}$ (Gambar 2). Megabentos terbanyak ditemukan dari species bivalvia A. granosa di Stasiun B2 periode September sebanyak $0,13 \mathrm{ind} / \mathrm{m}^{2}$, sedangkan paling sedikit ditemukan jenis $L$. laevigata dan $P$. nodosus di Stasiun PP1 periode Maret $\left(0,003 \mathrm{ind} / \mathrm{m}^{2}\right)$.

Hasil analisis tipe substrat dasar di ketiga lokasi penelitian didominasi oleh pasir. Walaupun sedimen di Stasiun TAl lebih banyak kandungan silt/clay, tetapi semakin ke

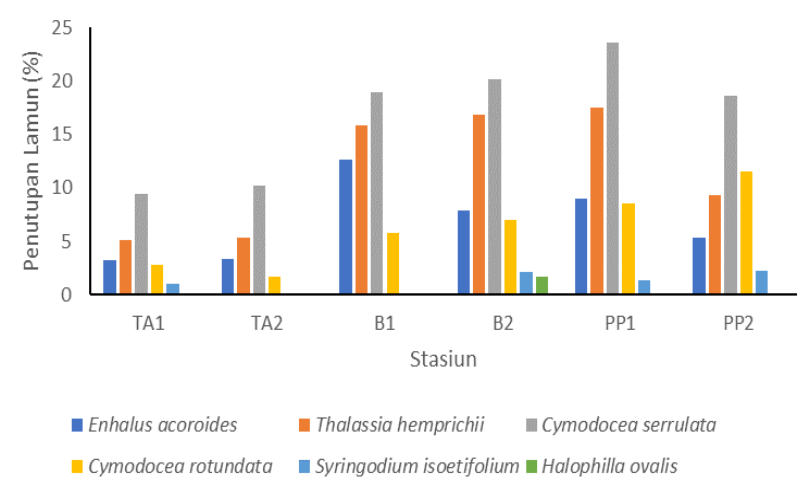

A arah laut semakin banyak kandungan pasir. Analisis hubungan antara kelimpahan megabentos dengan fraksi substrat dasar memperlihatkan hubungan linear yang relatif kuat, dengan persamaan $Y=0,008 x$ dengan nilai $R^{2}=0,7353$ ( $\left.r=0,8574\right)$ untuk periode Maret dan $Y=0,0086 x$ dengan nilai $R^{2}=0,7560$ $(r=0,8695)$ untuk periode September (Gambar 4). Grafik tersebut juga menunjukkan bahwa kepadatan megabentos semakin bertambah banyak pada lokasi dengan substrat dasar pasir dan kerikil/pecahan karang.

Kelimpahan megabentos selain dipengaruhi oleh penutupan lamun juga dipengaruhi oleh jenis substrat dasar (Gambar 3). Hubungan antara kelimpahan megabentos dan fraksi substrat dasar terlihat meningkat pada substrat berpasir. Sedangkan kelimpahan megabentos dari jenis $H$. atra merupakan yang tertinggi di padang lamun Pulau Panjang. Hal ini diduga karena substrat dasar yang lebih banyak terdiri dari pasir dan kerikil atau pecahan karang merupakan habitat utama yang dominan bagi teripang hitam. Hartati et al. (2019) menemukan bahwa teripang jenis $H$. atra lebih banyak ditemukan di habitat padang lamun dengan substrat pasir dan pecahan karang di Pulau Panjang.

Hasil analisis indeks ekologi untuk megabentos di ketiga lokasi penelitian menunjukkan bahwa indeks keanekaragaman pada kondisi sedang, indeks keseragaman dalam kondisi tinggi dan tidak ada biota yang mendominasi (Tabel 2).

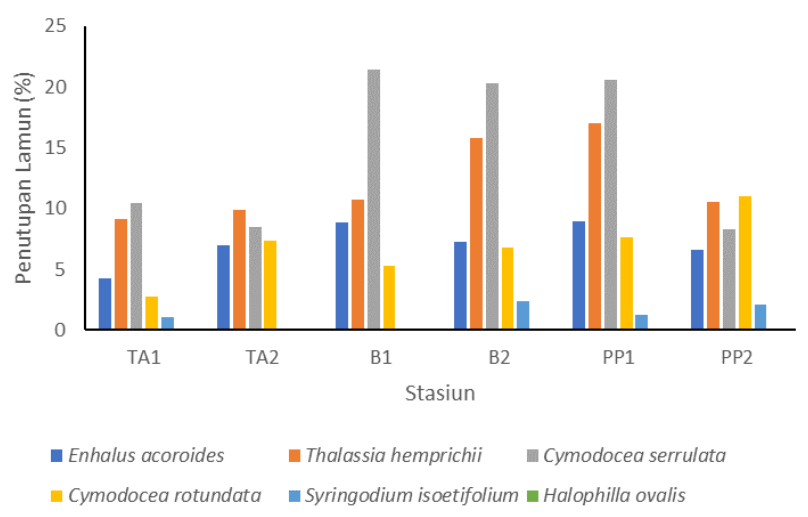

B

Gambar 2. Persentase penutupan lamun (\%) di perairan Teluk Awur (TA), Bandengan (B), dan Pulau Panjang Jepara (PP) pada Bulan Maret (A) dan September (B) 


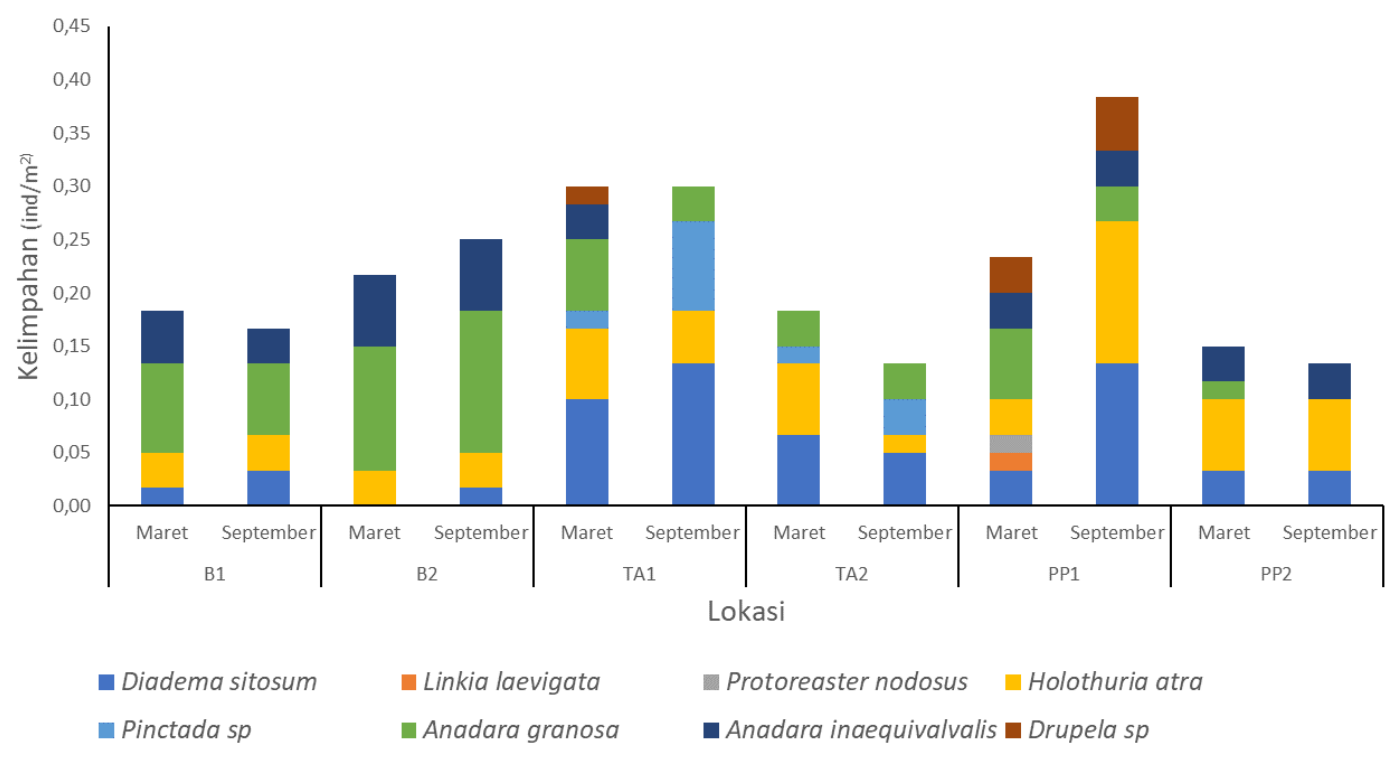

Gambar 3. Kelimpahan megabentos (Ind./ $\mathrm{m}^{2}$ ) pada padang lamun di perairan Teluk Awur (TA), Bandengan (B), dan Pulau Panjang Jepara (PP) pada Bulan Maret dan September.

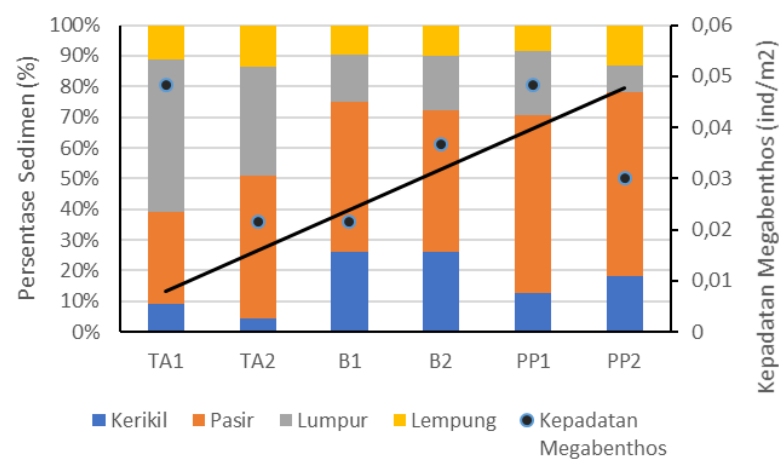

A

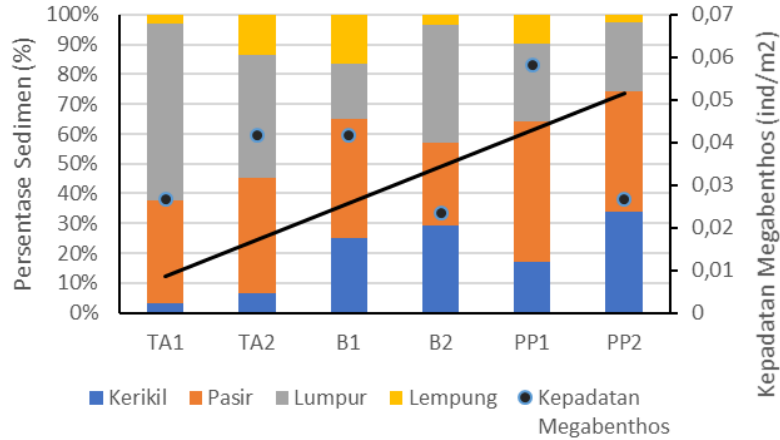

B

Gambar 4. Hubungan kelimpahan megabentos dengan fraksi subsrat dasar di ketiga lokasi penelitian (Teluk Awur, Bandengan, dan Pulau Panjang Jepara) pada Bulan Maret (A) dan September (B).

Hasil analisa indeks ekologi memperlihatkan bahwa Indeks Keanekaragaman termasuk kategori sedang untuk semua lokasi pengamatan, Indeks Keseragaman tinggi, serta Indeks Dominansi dan tidak ada biota yang mendominasi di semua lokasi pengamatan (Tabel 2). Indeks ekologi ini memperlihatkan bahwa kondisi keberadaan megabentos di ketiga lokasi pengamatan bahwa dalam kondisi yang stabil. Keanekaragaman biota megabentos yang relatif tinggi ini memperlihatkan bahwa walaupun kondisi padang lamun di beberapa lokasi dalam kondisi yang sedang penutupan lamunnya, namun didukung dengan kondisi parameter perairan yang optimal dapat memberikan habitat yang baik bagi kelimpahan megabentos di padang lamun tersebut. Bila dibandingkan dengan jumlah jenis biota bentik yang ditemukan di Pantai Parerengan Kab. Badung, dengan jumlah 17 spesies yang ditemukan oleh Indrawan et al. 
(2016) dan perairan Kualla Gigieng, Kab. Aceh Barat, dengan 12 jenis yang ditemukan oleh Fadli et al. (2012), jumlah spesies megabentos yang ditemukan di perairan Jepara masih tergolong beragam. Perbedaan jumlah spesies dalam setiap perairan dapat disebabkan karena faktor lingkungan, seperti kondisi kepadatan tutupan lamun, fraksi substrat dasar, keberadaan aktivitas masyarakat pesisir, waktu pengamatan dan aktivitas pelayaran (Tabasaramo et al., 2013; Wahab et al., 2019; Wijana et al., 2019).

Keterkaitan kelimpahan megabentos dengan karakteristik habitatnya di padang lamun di ketiga lokasi penelitian telah dilakukan analisis dengan Principal Component Analisys (PCA) (Gambar 5). Hasil analisis untuk stasiun Teluk Awur memperlihatkan bahwa kelimpahan megabentos pada kondisi lingkungan perairan yang berbeda berada pada sumbu komponen utama yang terpusat pada dua sumbu, yang terpusat pada sumbu F1 $(62,90 \%)$ dan F2 (28.77\%) dari keseluruhan persentase ragam total (Gambar. 5A). Hasil analisis ini memperlihatkan adanya dua kelompok, yaitu kelompok pertama yang dicirikan dengan parameter temperatur perairan, kedalaman perairan, oksigen terlarut, tutupan lamun, kelimpahan megabentos, kandungan pasir dan kerikil, sedangkan kelompok kedua dicirikan dengan kecerahan perairan dan $\mathrm{pH}$ perairan. Stasiun Bandengan terpusat pada tiga sumbu utama, yaitu sumbu F1 $(41,21 \%)$; F2 $(36,35 \%)$ dan F3 $(22,45 \%)$ dari keseluruhan persentase ragam total (Gambar. 5B). Berdasar analysis tersebut terlihat adanya tiga pengelompokan, dengan kelompok pertama dicirikan dengan parameter salinitas perairan,

Tabel 2. Indeks Keanekaragaman, Indeks Keseragaman dan Indeks Dominasi megabentos di padang lamun perairan Teluk Awur, Bandengan, dan Pulau Panjang Jepara pada Bulan Maret dan September 2018.

\begin{tabular}{|c|c|c|c|c|c|c|c|}
\hline \multirow{2}{*}{ Lokasi } & \multirow{2}{*}{$\begin{array}{l}\text { Periode } \\
\text { Sampling }\end{array}$} & \multicolumn{2}{|c|}{$\begin{array}{c}\text { Indeks } \\
\text { Keanekaragaman }\end{array}$} & \multicolumn{2}{|c|}{ Indeks Keseragaman } & \multicolumn{2}{|r|}{ Indeks Dominansi } \\
\hline & & Nilai & Kategori & Nilai & Kategori & Nilai & Kategori \\
\hline \multirow[t]{2}{*}{ TAl } & Maret & 2,31 & Sedang & 0,89 & $\begin{array}{c}\text { Tinggi, } \\
\text { komunitas stabil }\end{array}$ & 0,23 & $\begin{array}{c}\text { Tidak ada spesies yang } \\
\text { mendominasi }\end{array}$ \\
\hline & September & 1,82 & Sedang & 0,91 & $\begin{array}{c}\text { Tinggi, } \\
\text { komunitas stabil }\end{array}$ & 0,31 & $\begin{array}{c}\text { Tidak ada spesies yang } \\
\text { mendominasi }\end{array}$ \\
\hline \multirow[t]{2}{*}{ TA2 } & Maret & 1,82 & Sedang & 0,91 & $\begin{array}{c}\text { Tinggi, } \\
\text { komunitas stabil }\end{array}$ & 0,31 & $\begin{array}{c}\text { Tidak ada spesies yang } \\
\text { mendominasi }\end{array}$ \\
\hline & Ser & 1,91 & Sedang & 0,95 & $\begin{array}{l}\text { Tinggi, } \\
\text { komunitas stabil }\end{array}$ & 0,28 & $\begin{array}{c}\text { Tidak ada spesies yang } \\
\text { mendominasi }\end{array}$ \\
\hline \multirow[t]{2}{*}{ B1 } & Maret & 1,79 & Sedang & 0,89 & $\begin{array}{c}\text { Tinggi, } \\
\text { komunitas stabil }\end{array}$ & 0,32 & $\begin{array}{c}\text { Tidak ada spesies yang } \\
\text { mendominasi }\end{array}$ \\
\hline & Sep & 1,92 & Sedang & 0,96 & $\begin{array}{c}\text { Tinggi, } \\
\text { komunitas stabil }\end{array}$ & 0,28 & $\begin{array}{c}\text { Tidak ada spesies yang } \\
\text { mendominasi }\end{array}$ \\
\hline \multirow[t]{2}{*}{ B2 } & Maret & 1,42 & Sedang & 0,90 & $\begin{array}{c}\text { Tinggi, } \\
\text { komunitas stabil }\end{array}$ & 0,41 & $\begin{array}{c}\text { Tidak ada spesies yang } \\
\text { mendominasi }\end{array}$ \\
\hline & September & 1,64 & Sedang & 0,82 & $\begin{array}{c}\text { Tinggi, } \\
\text { komunitas stabil }\end{array}$ & 0,38 & $\begin{array}{c}\text { Tidak ada spesies yang } \\
\text { mendominasi }\end{array}$ \\
\hline \multirow[t]{2}{*}{ PP1 } & Maret & 2,66 & Sedang & 0,95 & $\begin{array}{c}\text { Tinggi, } \\
\text { komunitas stabil }\end{array}$ & 0,17 & $\begin{array}{c}\text { Tidak ada spesies yang } \\
\text { mendominasi }\end{array}$ \\
\hline & September & 2,06 & Sedang & 0,89 & $\begin{array}{c}\text { Tinggi, } \\
\text { komunitas stabil }\end{array}$ & 0,27 & $\begin{array}{c}\text { Tidak ada spesies yang } \\
\text { mendominasi }\end{array}$ \\
\hline \multirow[t]{2}{*}{ PP2 } & Maret & 1,84 & Sedang & 0,92 & $\begin{array}{c}\text { Tinggi, } \\
\text { komunitas stabil }\end{array}$ & 0,31 & $\begin{array}{c}\text { Tidak ada spesies yang } \\
\text { mendominasi }\end{array}$ \\
\hline & September & 1,50 & Sedang & 0,95 & $\begin{array}{c}\text { Tinggi, } \\
\text { komunitas stabil }\end{array}$ & 0,38 & $\begin{array}{c}\text { Tidak ada spesies yang } \\
\text { mendominasi }\end{array}$ \\
\hline
\end{tabular}


$\mathrm{pH}$, kecerahan perairan, dan kandungan lumpur, kelompok kedua dicirikan dengan kedalaman perairan, kelimpahan megabentos, tutupan lamun, pasir dan oksigen terlarut, serta kelompok ketiga dicirikan dengan temperatur perairan dan kerikil. Sedangkan hasil analisis PCA pada stasiun Pulau Panjang (Gambar 5C) terpusat pada tiga sumbu utama, yaitu sumbu Fl $(44,13 \%), \quad F 2 \quad(31,25 \%)$ and F3 $(24,08 \%)$. Berdasarkan analysis tersebut memperlihatkan adanya tiga pengelompokan karakteristik habitat, yaitu kelompok pertama dicirikan dengan temperatur perairan, $\mathrm{pH}$, dan kerikil, kelompok kedua dicirikan dengan salinitas, kedalaman perairan, kandungan pasir pada substrat dasar, kelimpahan megabentos dan tutupan lamun dan kelompok ketiga dicirikan oleh kecerahan, oksigen terlarut dan kandungan lumpur di substrat dasar.

Hasil analisis dengan Correspondence Analisys (CA) memperlihatkan adanya pengelompokan beberapa biota di beberapa lokasi pengamatan (Gambar 5). Grafik Correspondence Analysis memperlihatkan 4 kelompok megabentos di padang lamun, yaitu (i) 2 spesies, A. granosa dan $A$. inaequivalvalis yang sangat erat berasosiasi di perairan Bandengan; (ii) 2 spesies berasosiasi di perairan Teluk Awur, yaitu D. setosum dan Pinctada sp.; (iii) 3 spesies yang berasosiasi di perairan Pulau Panjang, yaitu L. laevigata, P. nodosus dan Drupela sp., serta (iv) 1 spesies tersebar di ketiga stasiun pengamatan, yaitu H. atra (Gambar 6).

Hasil analisis PCA memperlihatkan bahwa kelimpahan megabentos di padang lamun Teluk Awur lebih dicirikan berasosiasi dengan tutupan lamun, kandungan pasir dan kerikil/patahan karang. Sedangkan di padang lamun di perairan Bandengan, kelimpahan megabentos lebih dicirikan berasosiasi dengan habitat substrat berpasir dan tutupan lamun. Pada padang lamun di

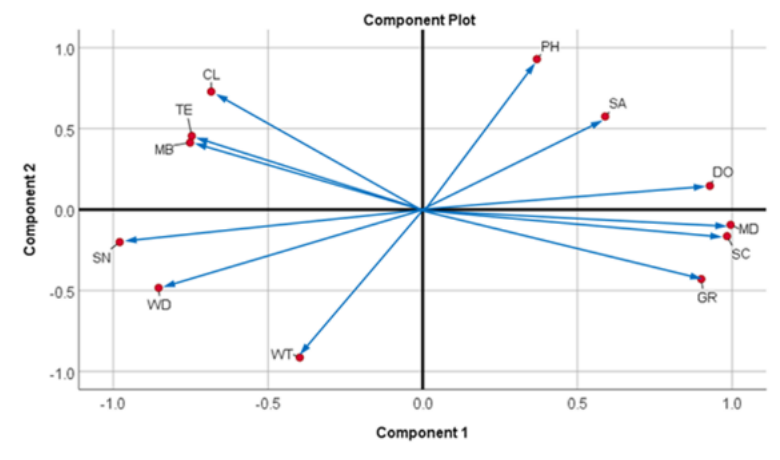

(a)

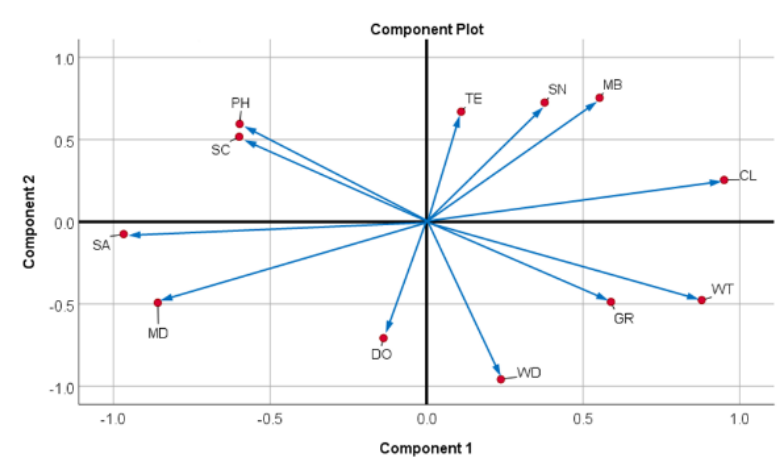

(b)

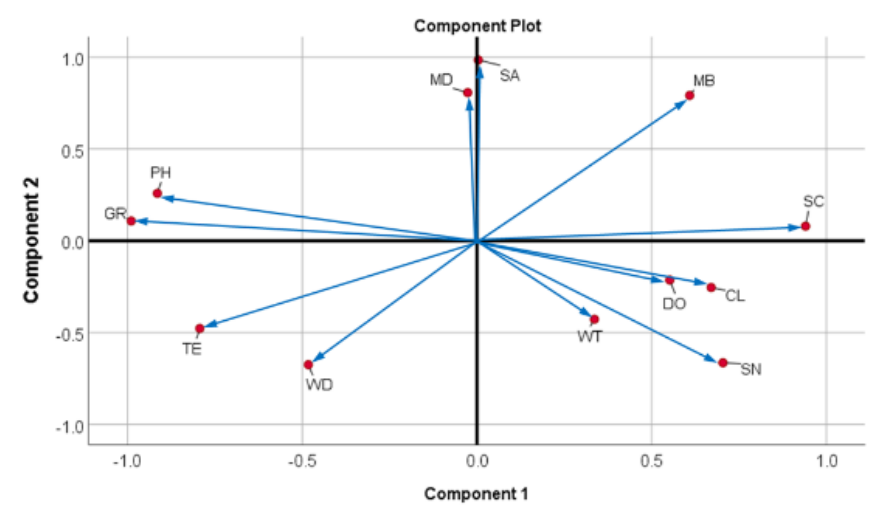

(c)

Gambar 5. Hasil analisis PCA keterkaitan kelimpahan megabentos dengan karakteristik habitatnya di padang lamun perairan Teluk Awur (a), Bandengan (b) dan Pulau Panjang (c). 


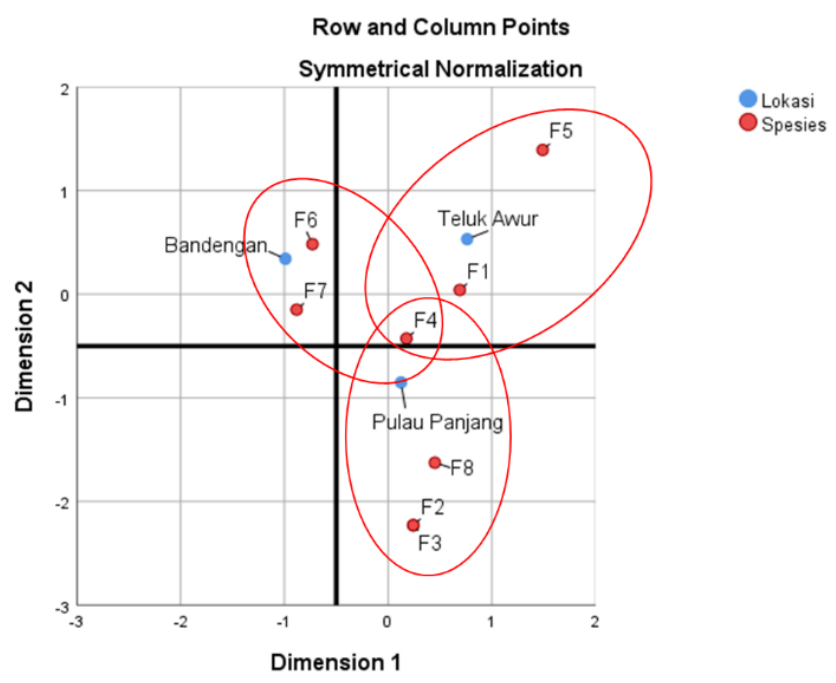

Gambar 6. Hasil analisis dengan Correspondence Analisys (CA) tentang keterkaitan kelimpahan megabentos dengan habitatnya pada padang lamun perairan Teluk Awur, Bandengan, dan Pulau Panjang Jepara.

Pulau Panjang, kelimpahan megabentos lebih dicirikan oleh substrat dasar berpasir dan tutupan lamun. Tutupan lamun, tipe substrat dasar merupakan faktor yang berpengaruh terhadap kelimlahan megabentos. Beberapa penelitian yang dilakukan oleh Herawati et al. (2017), Ningsih et al. (2020), dan Yunita et al. (2020) memperlihatkan bahwa jenis lamun, perbedaan penutupan lamun dan substrat dasar serta interaksi antara faktor tersebut serta interaksi kondisi parameter biotik dan abiotik perairan dapat mempengaruhi kelimpahan makrozoobentos di suatu habitat ekosistem padang lamun.

Jika dilihat dari hasil alanisis CA, teripang jenis $H$. atra ditemukan di ketiga lokasi pengamatan, dan tercatat terbanyak ditemukan di Pulau Panjang. Habitat dengan rataan padang lamun dengan substrat dasar pasir dan patahan karang merupakan habitat Utama dari teripang jenis ini. Penelitian yang telah dilakukan oleh Hartati et al., (2019) memperlihatkan bahwa teripang jenis $H$. atra merupakan biota yang banyak ditemukan di perairan lamun dengan substrat dasar berupa pasir bercampur patahan karang. Sedangkan untuk bintang laut jenis L. laevigata ditemukan di Pulau Panjang di rataan lamun yang bersebalahan dengan tubir terumbu karang. Daerah rataan lamun dan terumbu karang disukai oleh bintang laut tersebut karena diduga habitat tersebut kaya akan sumber makanan (Hartati et al., 2018). Drupela sp banyak ditemukan di lokasi Pulau Panjang, yang banyak tertangkap di rataan lamun yang berdekatan dengan terumbu karang. Hal ini diduga karena Drupela sp. merupakan biota utama yang banyak ditemukan di daerah karang sebagaimana yang dikemukakan oleh Arbi dan Sihaloho (2018). Selanjutnya keterkaitan antara lamun jenis Thalassia hemprichii dan bivalvia lebih dicirikan dengan kesamaan tipe substrat yang dijadikan sebagai habitatnya. Selain itu, asosiasi lamun dan bivalvia mempunyai keterkaitan yang kuat dalam siklus makanan. Menurut Allifah dan Rosmawati (2018) serasah lamun akan mengendap di dasar perairan dapat menjadi sumber makanan bagi bivalvia yang hidup di dasar perairan. Sesuai dengan hasil pelitian di atas, pada penelitian ini bivalvia jenis $A$. granosa dan $A$. inequlvalvalis melimpah banyak ditemukan di Stasiun Bandengan yang mempunyai tutupan lamun Thalassia hemprichii yang relative tinggi dengan substrat dasar berupa pasir berlumpur.

\section{KESIMPULAN}

Kelimpahan megabentos di ekosistem padang lamun sangat dipengaruhi oleh penutupan lamun dan type substrat dasar. Kondisi padang lamun terkait dengan penutupan lamun serta kandungan bahan 
organik dapat memberikan habitat dan sumber makanan bagi biota bentik yang berasosiasi di dalamnya.

\section{DAFTAR PUSTAKA}

Allifah, A.N., \& Rosmawati, T., 2018. Hubungan Kerapatan Lamun Dengan Kepadatan Bivalvia Di Pesisir Pantai Ori Kecamatan Pulau Haruku. Jurnal Biologi Science\& Education. 70 (1): 81-96

Arbi, U., \& Sihaloho, H.F., 2017. Panduan Pemantauan Megabenthos. Core Map CTI - LIPI

Arfiati, D., Herawati, E.Y., Buwono, N.R., \& Firdaus, A. 2019. Struktur Komunitas Makrozoobentos pada Ekosistem lamun di Paciran, Kabupaten Lamongan, Jawa Timur. Journal of Fisheries and Marine Research, 3(1):1-7. doi: 10.21776/ub.jfmr. 2019.003.01.1

Barus, B.S., Aryawati, R., Putri, W.A.E., Nurjuliasti, E., Diansyah, G., \& Sitorus, E., 2019. Hubungan N-Total dan C-Organik Sedimen dengan Makrozoobentos di Perairan Pulau Payung, Banyuasin, Sumatera Selatan. Jurnal Kelautan Tropis, 22(2):147-156. doi: 10.14710/jkt.v22i2.3770

Fadli, N., Setiawan, I., \& Fadhilah, N., 2012. Fauna Makrobentik di Perairan Kuala Gigieng Kab. Aceh Besar. Depik, (1): 4552. doi: 10.13170/depik.1.1.26

Hantanirina, J.M.O., \& Benbow, S., 2013. Diversity and Coverage of Seagrass Ecosystems in South-West Madagascar. African Journal of Marine Science, 35(2):291-297. doi: 10.2989/1814232X.201 3.800580

Hartati, R., Djunaedi, A., Hariyadi, \& Mujiyanto. 2012. Struktur Komunitas Padang Lamun di Perairan Pulau Kumbang, Kepulauan Karimunjawa. Ilmu Kelautan: Indonesian Journal of Marine Science. 17(4):217-225. doi: 10.14710/ik.ijms.17.4.217-225

Hartati, R., Meirawati, E., Redjeki, S., Riniatsih, I., \& Mahendrajaya, R.T. 2018. Jenis-jenis Bintang Laut dan Bulu babi (Asteroidea, Echinodea: Echinodermata) di Perairan Pulau Cilik, Kepulauan Karimunjawa. Jurnal Kelautan Tropis. 21(1):41-48. doi: 10.14710/jkt.v21i1.2417

Hartati. R, Zainuri, M. Ambariyanto, A. Ayodya, F.P., Widianingsih, W., Mustagfirin, M. \& Soegianto, A., 2019. Initial Assessment of
Holothuria atra Population in Panjang Islands. Ecology, environment \& conservation, 25 (Suppl. Issues): S1-S6.

Herawati, P., Barus, T.A., \& Wahyuningsih, H., 2017. Keanekaragaman Makrozoobentos dan Hubungannya dengan Penutupan Lamun (Seagrass) di Perairan Mandailing Natal Sumatera Utara. Jurnal Biosains. 3(2):66-74. doi: 10.24114/jbio.v3i2.7434

Indrawan, G.S., Yusup, D.S., \& Ulinuha, D. 2016. Asosiasi Makrozoobentos pada Padang Lamun di Pantai Merta Segara, Sanur, Bali. Jurnal Biologi. 20(1):11-16.

Ningsih, S.W., Setyati, W.A., \& Taufiq-Spj, N., 2020. Tingkat Kelimpahan Makrozoobentos di Padang Lamun Perairan Telaga dan Pulau Bengkoang, Karimunjawa. Journal of marine Research. 9(3):223-229. doi: 10.14710/jmr.v9i3.27418

Park, J.M., \& Kwak, S.N., 2018. Seagrass Fish Assemblages in the Nambe Island, Korea: The Influence of Sagrass Vegetation and Biomass. Journal of Sea Research. 139(2018): 41-49.

Purnawan, A., 2015. Kajian Awal Granulometri pada Kawasan Lamun dan Terumbu Karang: Kajian Khusus di Gugusan Pulau Pari Kepulauan Seribu. Depik (42):107-1 14. doi: 10.13170/depik.4.2.2640.

Rahmawati, S., Fahmi \& Yusup, S.D., 2012. Struktur Komunitas Padang Lamun dan Ikan Pantai di Pantai Kendari Sulawesi Selatan. IImu Kelautan: Indonesian Journal of Marine Science. 17(4):190-198. doi: 10.14710/ik.ijms.17.4.190-198

Rahmawati, S., Irawan, A., Indarto, S.H., \& Azkab, M.H., 2014. Panduan Pemantauan Kondisi Padang Lamun. CORE MAP - P2O LIPI. Jakarta.

Riniatsih, I., 2016. Distribusi Jenis Lamun Dihubungkan dengan Sebaran Nutrien Perairan di Padang Lamun Teluk Awur Jepara. Jurnal Kelautan Tropis, 19(2):101107. doi: 10.14710/jkt.v19i2.824

Riniatsih, I., \& Munasik. 2017. Keanekaragaman Megabentos yang Berasosiasi di Ekosistem Padang lamun Perairan Wailiti, Maumere Kabupaten Sikka, Nusa Tenggara Timur. Jurnal Kelautan Tropis, 20(1):55-59. doi: 10.14710/jkt.v20i1.1357

Riniatsih, I., Ambariyanto, A., Yudiati, E., Hartati, R., Widianingsih, W., \& Mahendrajaya, R.T., 2019. Diversity Species and Condition of Seagrass Ecosystem in Teluk Awur and 
Prawean Jepara. IOP Conference Series: Earth and Environmental Science, 236(1): p. 012052.

Suharsono \& Sumadhiharga, O.K., 2014. Panduan Monitoring Kesehatan Terumbu Karang; Terumbu Karang, Ikan Karang, Megabentos dan Penulisan Laporan. Coremap CTI. Lembaga IImU Pengetahuan Indonesia

Tasabaramo, I.A., Ambo-Rappe, R., \& Amran, M.A., 2013. Keberadaan Makrozoobentos Hubungannya Dengan Penutupan Lamun di Perairan Pulau Bonebatang, Makassar. Jurnal IImu Kelautan dan Perikanan, 23(1):21-28.

Udden, J.A., 2015. Mechanical Composition of Clasic Sedimen. Bulletin of Geological Societi of Amerika. 24:656-744.
Wahab, I., Madupa, H., Kawaroe, M., \& Nurafni. 2019. Analisis Kepadatan Makrozoobentos pada Fase Bulan Berbeda di Lamun, Pulau Panggang, Kepulauan seribu Jakarta. Jurnal Teknologi Perikanan dan Kelautan, 10(1): 93-107. doi: 10.24319/jtpk.10.93-107

Wijana, I.M.S., Ernawati, N.M, \& Pratiwi, M.A. 2019. Keanekaragaman Lamun dan Makrozoobentos sebagai Indikator Kondisi Perairan Pantai Sindhu, Sanur, Bali. Jurnal Ecotrophic. 13(2):238-247. doi: 10.24843/EJES.2019.v13.i02.p1 1

Yunita, R.R., Suryanti, S., \& Latifah, N., 2020. Biodiversitas Echinodermata pada Ekosistem Lamun di Perairan Pulau Karimunjawa, Jepara. Jurnal Kelautan Tropis. 23(1):47-56. doi: 10.14710/jkt. v23i1. 3384 